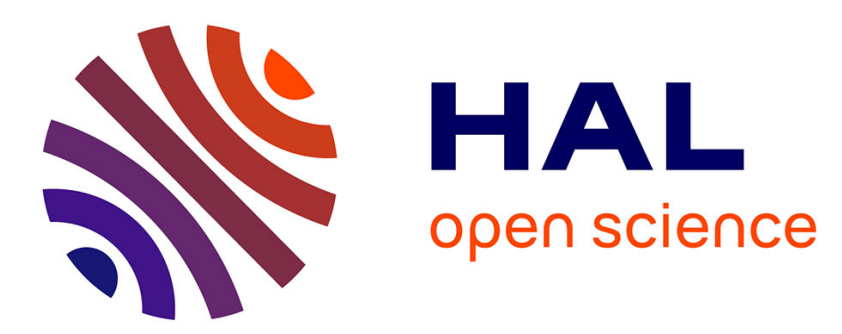

\title{
Study of the influence of the supersaturation coefficient on scaling rate using the pre-calcified surface of a quartz crystal microbalance
}

Hélène Cheap-Charpentier, Olivier Horner, Jean Lédion, Hubert Perrot

\section{- To cite this version:}

Hélène Cheap-Charpentier, Olivier Horner, Jean Lédion, Hubert Perrot. Study of the influence of the supersaturation coefficient on scaling rate using the pre-calcified surface of a quartz crystal microbalance. Water Research, 2018, 142, pp.347 - 353. 10.1016/j.watres.2018.05.052 . hal-01836183

\section{HAL Id: hal-01836183 \\ https://hal.sorbonne-universite.fr/hal-01836183}

Submitted on 17 Dec 2018

HAL is a multi-disciplinary open access archive for the deposit and dissemination of scientific research documents, whether they are published or not. The documents may come from teaching and research institutions in France or abroad, or from public or private research centers.
L'archive ouverte pluridisciplinaire HAL, est destinée au dépôt et à la diffusion de documents scientifiques de niveau recherche, publiés ou non, émanant des établissements d'enseignement et de recherche français ou étrangers, des laboratoires publics ou privés. 


\section{Study of the influence of the supersaturation coefficient on scaling rate} using the pre-calcified surface of a quartz crystal microbalance

Hélène Cheap-Charpentier ${ }^{\mathrm{a}, \mathrm{b}^{*}}$, Olivier Horner ${ }^{\mathrm{a}, \mathrm{b}}$, Jean Lédion ${ }^{\mathrm{a}, \mathrm{c}}$, and Hubert Perrot ${ }^{\mathrm{b}}$

${ }^{a}$ EPF - Graduate School of Engineering, 3 bis rue Lakanal, 92330 Sceaux, France.

b Sorbonne Universités, UPMC Université Paris 06, CNRS, Laboratoire Interfaces et Systèmes Électrochimiques, 4 place Jussieu, F-75005, Paris, France.

${ }^{\mathrm{c}}$ AMVALOR, 151 Boulevard de l'Hôpital, 75013 Paris, France.

* Corresponding author: Tel.: +33141134285

E-mail address: helene.cheap-charpentier@epf.fr (H. Cheap-Charpentier)

\section{Abstract}

Scale deposition is a common issue in industrial plants, which creates technical problems, i.e. reduction of heat transfer, decrease of flow rate due to an obstruction of pipes. Therefore, the development of some appropriate methods based on well suitable in situ sensors to evaluate and predict the scaling propensity of water is a major concern in current research. This would be a good strategy for the optimization of anti-scaling treatments. In this study, scaling tests were carried out using a sensitive sensor, which has been developed using a quartz crystal microbalance with a pre-calcified electrode surface (SQCM). This technique allowed studying the influence of the supersaturation on the scaling rate. The set-up was tested with different water samples which were brought to a given supersaturation coefficient by degassing the dissolved $\mathrm{CO}_{2}$. The prediction of the scaling propensity of water 
was then possible through the relationship between the scaling rate on a pre-calcified surface and the supersaturation coefficient. In addition, the kinetics of $\mathrm{CaCO}_{3}$ deposit on the precalcified SQCM surface was found to be slower for natural water than for synthetic water (same calcium concentration). Furthermore, the activation energy for scale deposit, in synthetic water, was found to be $22 \mathrm{~kJ} \cdot \mathrm{mol}^{-1}$, which may be related to the diffusion of ions and/or $\mathrm{CaCO}_{3}$ nuclei in solution.

Keywords: calcium carbonate; scaling propensity; quartz crystal microbalance; pre-calcified surface.

Abbreviations:

QCM: Quartz Crystal Microbalance with a regular bare electrode surface;

SQCM: Quartz Crystal Microbalance with a pre-calcified electrode surface;

TOC: Total Organic Carbon;

XRD: X-Ray Diffraction

\section{Introduction}

Scale deposit on solid surfaces causes serious problems in many industries using or processing water, e.g. in cooling systems (Abd-El-Khaled and Abd-El-Nabey, 2013) or in heat exchangers (Yang, 2002). Indeed, the thickness of the scale deposit may limit thermal exchanges or the water flow in pipes. The use of chemicals is a common approach to control scale deposit. However, those chemicals may have an important impact on environment, i.e. in the eutrophication process. On the one hand, scale deposit could occur when water becomes supersaturated, i.e the product of ions activities, $\left[\mathrm{Ca}^{2+}\right] \times\left[\mathrm{CO}_{3}^{2-}\right]$, exceeds the solubility product $\mathrm{K}_{\mathrm{sp}}$ of $\mathrm{CaCO}_{3}$ (Xyla, et al., 1991). On the other hand, scale deposit may 
take place due to an external cause, i.e. the introduction of a substrate or seed crystals (Donnet et al., 2010). Thus, preventing scale formation has raised a great interest. It is relevant to develop some efficient methods based on in situ sensors to follow the scaling propensity of water in order to prevent scale deposit.

Some methods based on the determination of the scaling rates have been developed in order to estimate the scaling propensity of water (Hui and Lédion, 2002; Leroy et al., 1993; Al Nasser and Al Salhi, 2013). For example, Hui et al. (Hui et al., 2003) have studied the scaling rates using witness tubes with pre-calcified surface. Zhang et al. (Zhang et al., 2001) considered thermodynamic models in order to evaluate the tendency for scaling from solutions and kinetics models to predict the rate of scaling. The use of chronoamperometry at constant reduction potential was the more fruitful approach to investigate the scaling rate (Gabrielli et al., 1996; Lédion et al., 1985). However, correlation between supersaturation coefficient and scaling rate on a solid surface was not very well developed in literature. Some discrepancies were detected between real deposit on solid surfaces and scaling rates estimated from predictive models based on thermodynamic data where precipitation tendency were predicted (Hasson et al., 1996).

Recently, a quartz crystal microbalance with a pre-calcified sensitive surface (SQCM) has been developed (Chao et al., 2014a). The sensitive surface could be used as an adsorption layer for $\mathrm{CaCO}_{3}$ nuclei present in water. It was installed in a cell simulating an industrial fluid stream with a laminar flow. A preliminary relationship was obtained between the instantaneous scaling rate and the supersaturation coefficient of synthetic water at different concentrations of $\mathrm{Ca}^{2+}\left(\left[\mathrm{Ca}^{2+}\right]\right.$ in the range $\left.60 \mathrm{mg} \cdot \mathrm{L}^{-1}-200 \mathrm{mg} \cdot \mathrm{L}^{-1}\right)$ and at a given temperature $\left(\mathrm{T}=35^{\circ} \mathrm{C}\right)$. This opens the possibility to quantify the scaling propensity of a tested water.

In this work, the pre-calcified QCM electrode was installed in a miniaturized lab-made cell. This original set-up was tested with synthetic water which was brought to a given 
supersaturation coefficient related to the precipitation of calcium carbonate by $\mathrm{CO}_{2}$ degassing (Gauthier et al., 2012; Chao, 2014b). Indeed, only calcium carbonate $\left(\mathrm{CaCO}_{3}\right)$, one of the most abundant mineral scale compound (Keysar, 1994), will be considered in this study. This work is focused on calcium carbonate scaling, i.e. the deposit of calcium carbonate on a surface, and not with calcium carbonate precipitation in solution, i.e. the appearance of a $\mathrm{Ca}$ $\mathrm{CO}_{3}$ solid phase within the bulk solution. The deposit kinetics of calcium carbonate nuclei on the active electrode of the SQCM was measured at different supersaturation coefficients for two temperatures $\left(\mathrm{T}=30^{\circ} \mathrm{C}\right.$ and $\left.40^{\circ} \mathrm{C}\right)$, either for a synthetic or a natural water. Indeed, it was possible to compare, in a very sensitive way, the scaling propensity of a synthetic and a natural mineral water (same calcium concentration). Thus, this work investigates, thanks to the pre-calcified QCM electrode, the effect of several parameters like supersaturation level, temperature and composition of water on scaling rate. For the first time, the activation energy of the scaling process on the pre-calcified surface, for synthetic water, was investigated.

\section{Materials and methods}

\subsection{Reactants}

Synthetic waters were pure solutions, which only contained $\mathrm{Ca}^{2+}$ and $\mathrm{CO}_{3}{ }^{2-}$ ions. The synthetic waters (100 or $200 \mathrm{mg} / \mathrm{L}$ in calcium, depending on the experiment) used in this work were prepared by dissolving solid calcium carbonate (AnalaR NORMAPUR VWR, 99.7\% purity) in pure water (Milli.Q water, $18.2 \mathrm{M} \Omega \mathrm{cm}$ resistivity and TOC $<5 \mathrm{mg} \mathrm{L}-1$ ) by bubbling $\mathrm{CO}_{2}$ gas. After the solid dissolution, the $\mathrm{pH}$ of the solution was about 5.2-5.5. Under those experimental conditions, no spontaneous precipitation of $\mathrm{CaCO}_{3}$ occurred. The solution was then filtered with a Millipore filter (514-8073 Whatman, $0.45 \mu \mathrm{m}$ porosity) to remove any impurities. Salvetat ${ }^{\circledR}$ water is a commercial natural water, which contains the following 
1 elements (Table 1). The ions and TOC concentrations in Salvetat water have been determined

2 according to IANESCO laboratory (Poitiers, France) titration report.

3

4 Table 1: Concentration of ions in Salvetat ${ }^{\circledR}$ water.

\begin{tabular}{ccccccccc}
\hline Ions & $\mathrm{Ca}^{2+}$ & $\mathrm{Mg}^{2+}$ & $\mathrm{HCO}_{3}^{-}$ & $\mathrm{Cl}^{-}$ & $\mathrm{SO}_{4}{ }^{2-}$ & $\mathrm{Na}^{+}$ & $\mathrm{K}^{+}$ & $\mathrm{TOC}$ \\
\hline Concentration & 180 & 8.7 & 634 & 4.6 & 31 & 5.7 & 1.7 & 0.4 \\
$\left(\mathrm{mg} . \mathrm{L}^{-1}\right)$ & & & & & & & & \\
\hline
\end{tabular}

5

6

7

8

9

10

11

\subsection{QCM set-up}

A quartz crystal microbalance with a pre-calcified electrode surface (SQCM) was used to measure the mass of calcium carbonate deposited on the pre-calcified surface (Figure 1).

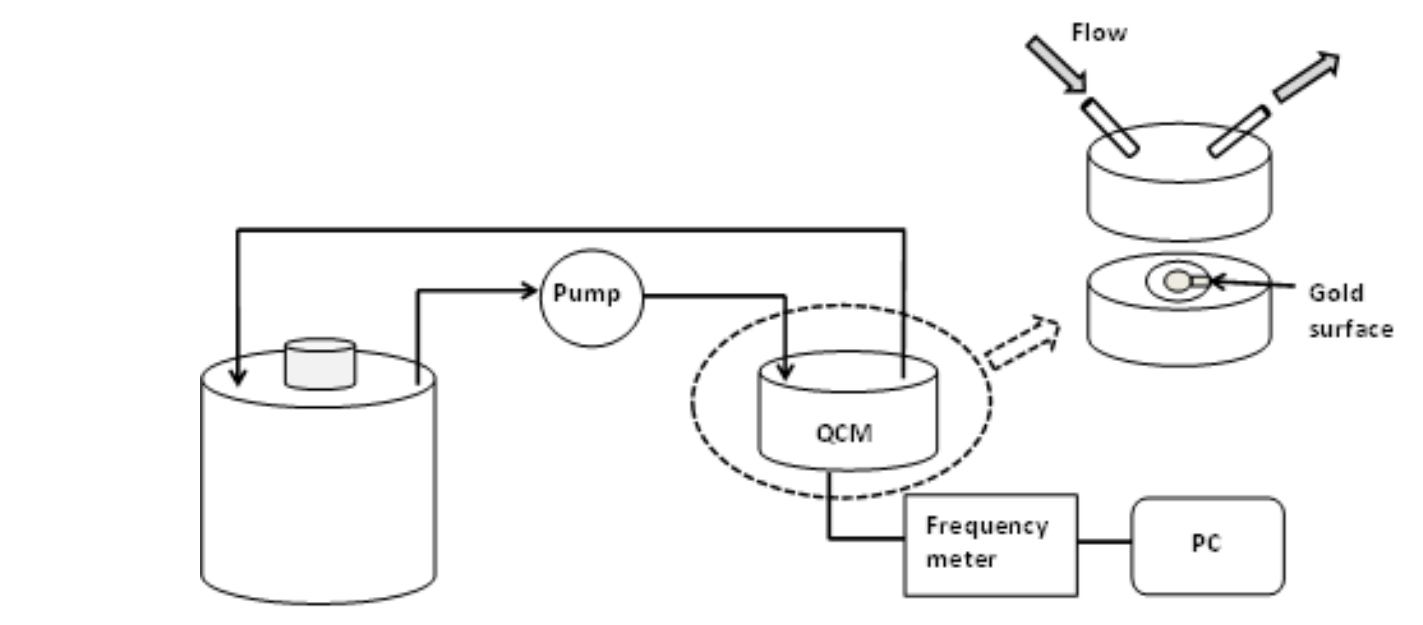
(1) 2

Figure 1: Scheme of a SQCM set up.

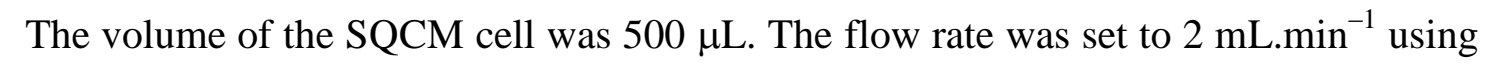
a peristaltic pump. The water jet arrived at $45^{\circ}$ on the flat surface of the modified electrode. 
1 The bare surface of the electrode consisted in a $5 \mathrm{~mm}$ diameter gold disc covering a $9 \mathrm{MHz}$

2 AT cut quartz crystal resonator (AWS, Spain). the bare gold electrode acting as a working electrode. All the electrodes were inserted in a

5 submerged impinging jet cell (flow rate of $\left.300 \mathrm{~mL} \cdot \mathrm{min}^{-1}\right)$, with a synthetic water $\left(200 \mathrm{mg} . \mathrm{L}^{-1}\right.$ $\left.6 \mathrm{Ca}^{2+}\right)$ at $30^{\circ} \mathrm{C}$.

7 The frequency of the microbalance device was measured by a frequency-counter (Fluke 8 PM6685). The mass deposited onto the bare or the pre-calcified surface of the sensor was measured over time from the microbalance frequency change (Bizet et al., 2000; Chao et al., 2014a). The frequency change $\Delta \mathrm{f}$ of the quartz resonator due to the deposition of the scale on the working electrode was proportional to the mass change $\Delta \mathrm{m}$ according to Sauerbrey equation (Sauerbrey et al., 1959):

where $\mathrm{K}_{\mathrm{s}}$ is the sensitivity factor $\left(\mathrm{K}_{\mathrm{s}}\right)^{-1}=1,09 \mathrm{ng}$ per $\mathrm{Hz}$ for an electrode area of $0.2 \mathrm{~cm}^{2}$.

\subsection{Preparation of water with a given supersaturation coefficient $\delta$}

Stable solutions of calcium carbonate were brought to a given supersaturation coefficient ( $\delta$ coefficient) by $\mathrm{CO}_{2}$ degassing (Lédion et al., 1997; Gauthier et al., 2012; Chao et al., 2014b). Indeed, the degassing of dissolved $\mathrm{CO}_{2}$ is accelerated by stirring the water sample. As the $\mathrm{CO}_{2}$ degasses, the concentration of $\left[\mathrm{H}^{+}\right]$decreases, so the concentration of $\left[\mathrm{OH}^{-}\right]$or the $\mathrm{pH}$ increases according to the following equations:

$$
\begin{aligned}
& \mathrm{CO}_{2 \text { dissolved }} \leftrightarrow \mathrm{CO}_{2} \text { atmospheric } \\
& \mathrm{HCO}_{3}{ }^{-} \leftrightarrow \mathrm{CO}_{2} \text { dissolved } \\
& \mathrm{H}^{+}+\mathrm{OH}^{-}
\end{aligned}
$$


Supersaturation coefficient $\delta$, the extent of deviation of the solution from the equilibrium condition, is the driving force for the formation of a $\mathrm{CaCO}_{3}$ crystalline phase in aqueous

solutions. $\delta$ is defined according to the following equation (5): (Legrand et al., 1981)

$$
\delta=\left[\mathrm{Ca}^{2+}\right] \times\left[\mathrm{CO}_{3}^{2-}\right] / \mathrm{K}_{\mathrm{sp}}^{\prime}
$$

where $\left[\mathrm{Ca}^{2+}\right]$ and $\left[\mathrm{CO}_{3}{ }^{2-}\right]$ are the concentrations of calcium ions and carbonate ions respectively, and $\mathrm{K}_{\mathrm{sp}}^{\prime}$ is the apparent solubility product of calcium carbonate. As stated above, the supersaturation level $\delta$ of the studied water was increased by using a moderate stirring (400 rpm) of the solution. For each test, the synthetic water was initially brought to the same supersaturation coefficient $(\delta=40)$, below the homogeneous precipitation threshold. The $\mathrm{pH}$ of the solution was measured as a function of time using a pH-meter (Radiometer pHM220). The pH electrode was purchased from Radiometer Analytical, and the saturated calomel electrode (Radiometer Analytical) was used as a reference electrode. When the solution reached a given $\delta$ value (i.e. a given $\mathrm{pH}$ value), the stirring was stopped and all the openings of the beaker were hermetically sealed. The value of $\delta$ was maintained below the spontaneous precipitation threshold.

\section{4. $X$-ray diffraction $(X R D)$}

The XRD method was used in order to determine crystalline polymorphs of $\mathrm{CaCO}_{3}$ formed on the gold surface. XRD measurements were performed at room temperature with $\mathrm{Cu}-\mathrm{K} \alpha$ radiation $(1.52 \AA)$ using a Panalytical (Empyrean Diffractometer Panalytical) device with prefix configuration. Crystalline forms of the $\mathrm{CaCO}_{3}$ layer forming the pre-calcified surface were determined from spectra obtained by XRD measurements.

\subsection{Scaling rate equation}




$$
R \underset{k-}{\stackrel{k_{+}}{\rightleftarrows}} P
$$

4

5 where $\mathrm{R}$ represents $\mathrm{Ca}^{2+}$ and $\mathrm{CO}_{3}{ }^{2-}$ species and $\mathrm{P}$ represents calcium carbonate in solid phase.

$6 \mathrm{k}_{+}$and $\mathrm{k}_{-}$are the rate constants related to the reactions of precipitation or dissolution, 7 respectively. The relationship between the reaction rate, $V_{S}$, and the free energy, $\Delta \mathrm{G}$ is given 8 by equation (7): (Blum et al., 1990)

$$
V_{S}=\frac{d\left[\mathrm{CaCO}_{3}\right]}{d t}=-\frac{s}{V} k\left[1-\exp \left(\frac{\Delta G_{p r e}+\Delta G_{d i s}}{R_{g} T}\right)\right]^{n}=-\frac{s}{V} k\left[1-\exp \left(\frac{\Delta G}{R_{g} T}\right)\right]^{n}
$$

$$
\log \mathrm{Vs}=\log \mathrm{k}^{\prime}+\mathrm{n} \times \log \left[\delta^{1 / 2}-1\right]
$$

$$
\Delta G=\frac{R_{g} T}{2} \ln \delta
$$

where $V_{S}$ is the reaction rate, $S$ is the reaction surface, $V$ is the volume of the solution, $\Delta G_{\text {pre }}$ and $\Delta \mathrm{G}_{\mathrm{dis}}$ are, respectively, the free energy released in $\mathrm{CaCO}_{3}$ formation process and the free energy expended in dissolution of calcium carbonate, $\Delta \mathrm{G}$ is the total free energy of the reaction, $\mathrm{k}$ is the rate constant of the reaction and $\mathrm{n}$ the reaction order. $\Delta \mathrm{G}$ depends on the For the scaling rate $(\delta>1)$, equation 7 can be rewritten as: 
1 where $V_{S}\left(\mu \mathrm{g} \cdot \mathrm{cm}^{-2} \cdot \mathrm{min}^{-1}\right)$ is the scaling rate, $\mathrm{k}^{\prime}$ is the rate constant for deposit $\left(\mathrm{k}^{\prime}=(\mathrm{S} / \mathrm{V}) \mathrm{k}\right)$

2 and $\mathrm{n}$ is the apparent reaction order (Morse et al., 2007).

3

4

5

\section{Results and discussion}

\subsection{Pre-calcification of the sensitive surface of QCM}

(1)

The sensitive surface of QCM can be initially covered by a calcium carbonate layer to obtain the SQCM sensor (Gabrielli et al., 1998; Peronno et al., 2015). The potential applied to the working electrode was $-1 \mathrm{~V} / \mathrm{SCE}$, leading to the reduction of the dissolved dioxygen to produce hydroxyl ions. The formed hydroxyl ions increased the local $\mathrm{pH}$ near the electrode surface (Tlili et al., 2003) which led to the transformation of bicarbonate ions into carbonate ions. The carbonate ions reacted with calcium ions to form a $\mathrm{CaCO}_{3}$ precipitate on the surface of the working electrode.

The pre-calcifying experiment was stopped when the current, recorded during calcium carbonate deposition, reached a low residual constant value of a few micro amps. This indicates that the electrode surface was fully recovered by the $\mathrm{CaCO}_{3}$ film. In these experimental conditions, the solid phase formed on the electrode surface was pure calcite, the most thermodynamics form of calcium carbonate (Morse et al., 2007), as shown in Figure 2: 


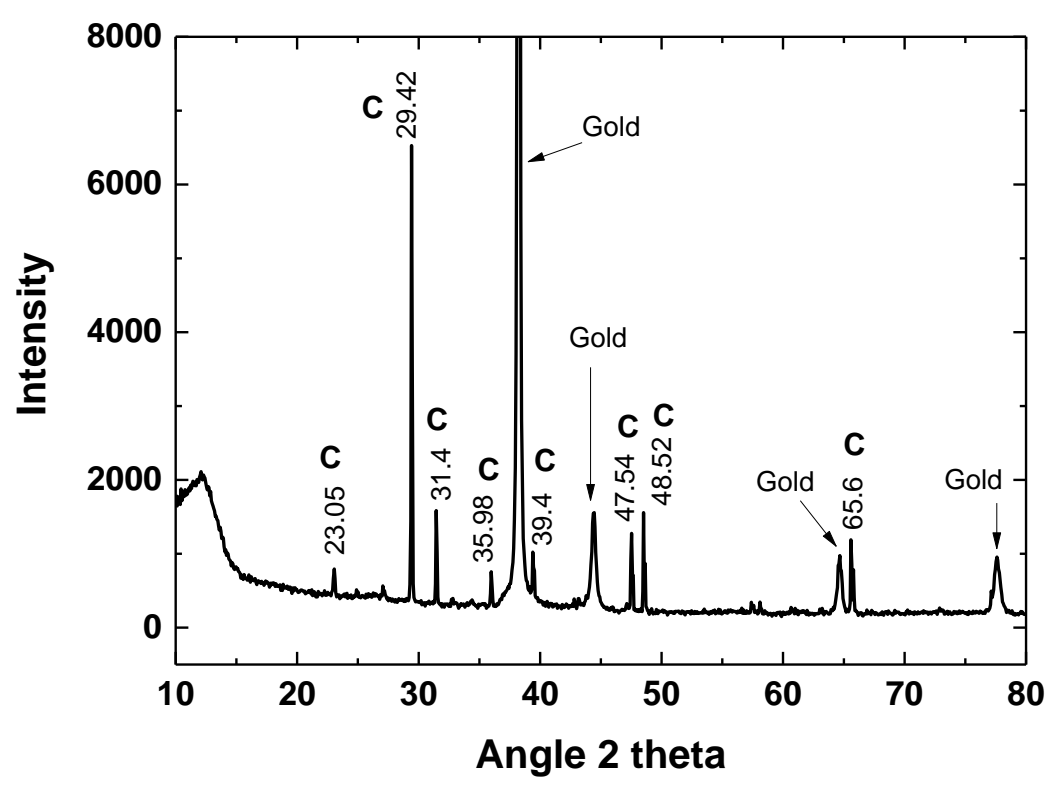

2 Figure 2: $\mathrm{XRD}$ spectrum of the $\mathrm{CaCO}_{3}$ layer formed during the pre-calcifying process.

3 C: calcite.

4

Obtaining pure calcite is likely to be due to a moderate kinetics of deposition. If the

6 kinetics of deposition would increase, a mixture of calcite and aragonite would be observed.

7 This process of layer formation is highly reproducible and the $\mathrm{CaCO}_{3}$ layer was stable over 8 time (Gabrielli et al., 1999).

9

3.2. Comparison of the bare surface and the pre-calcified surface (pure calcite) of the sensor towards scaling

Figure 3 shows the curves of mass change as a function of time for synthetic water $\left(\left[\mathrm{Ca}^{2+}\right]=200 \mathrm{mg} / \mathrm{L}, \mathrm{T}=30^{\circ} \mathrm{C}\right)$ for a pre-calcified surface (pure calcite), and a bare gold surface as the sensitive part of the sensor. 


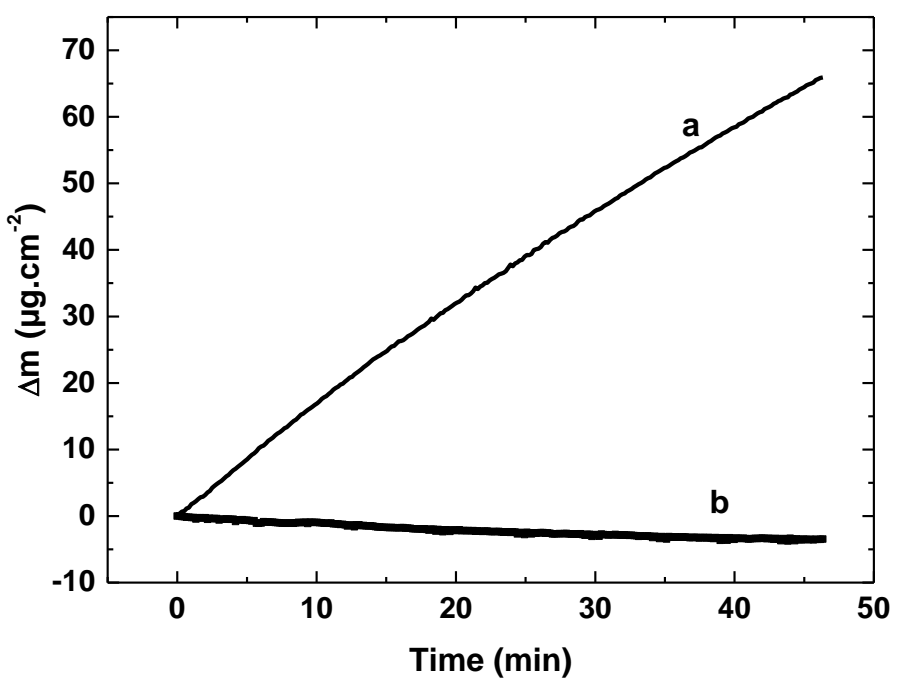

2 Figure 3: Mass change as a function of time for synthetic water with (a) a pre-calcified

3 surface (pure calcite) (scaling time Vs=1.2 $\mu \mathrm{g} \cdot \mathrm{cm}^{-2} \cdot \mathrm{min}^{-1}$ ) and (b) a bare gold surface (initial $4 \quad\left[\mathrm{Ca}^{2+}\right]=200 \mathrm{mg} / \mathrm{L}, \mathrm{T}=30^{\circ} \mathrm{C}$, flow rate $\left.=2 \mathrm{~mL} \cdot \mathrm{min}^{-1}, \delta=40\right)$.

In Figure $3 b$, the mass change detected on the bare gold surface was roughly constant. This indicates that no $\mathrm{CaCO}_{3}$ deposition was detected by the QCM sensor with no precalcified surface. On the contrary, $\mathrm{CaCO}_{3}$ deposit is immediately observed on the precalcified surface of the sensor (Figure 3a). It should be noticed that the mass deposited on the pre-calcified surface increased linearly over time.

In this work, the pre-calcified surface of the sensor is very sensitive towards $\mathrm{CaCO}_{3}$ nuclei adsorption, compared to a bare gold surface. This result validated the use of a precalcified surface for scaling tests. This is in line with the results obtained from the literature. (Hui et al., 2003) on titanium or copper tubes. Indeed, they showed that the scaling rate was enhanced when the inner surface of the tubes was pre-calcified.

\subsection{Supersaturation level vs scaling rate for synthetic water}



by the SQCM device for synthetic water with given $\delta$ coefficients (see Materials and methods). Figure 4 shows the influence of the supersaturation level over the mass change on a pre-calcified surface (pure calcite) as a function of time.

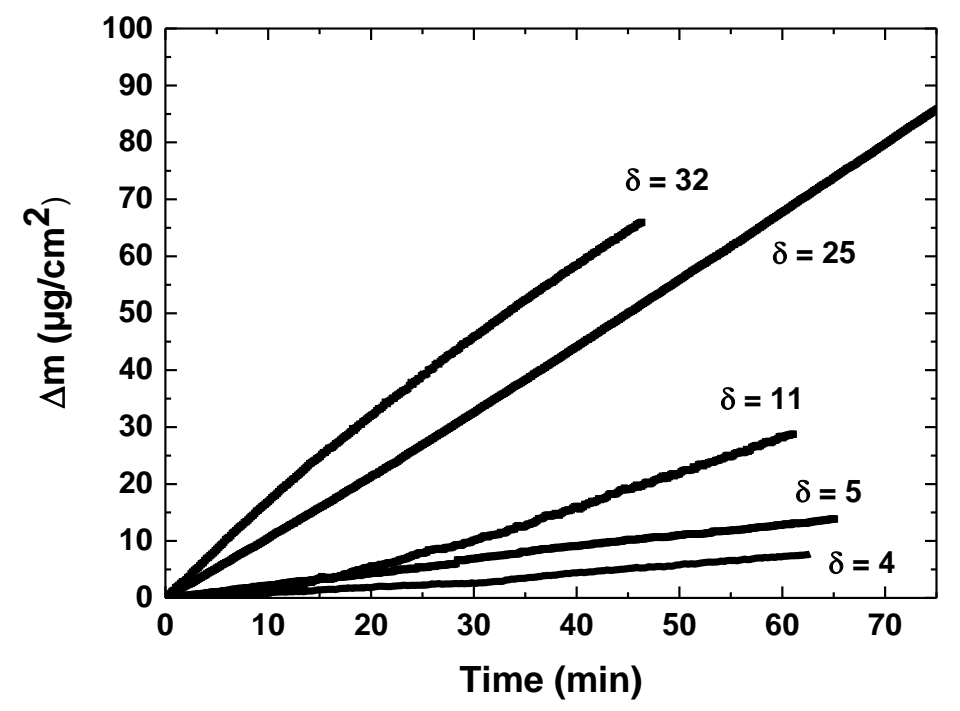

Figure 3 shows that the mass change on the pre-calcified surface (pure calcite) depends strongly on the supersaturation level of the studied solution (with the others parameters constant). The higher was the degree of supersaturation, the faster were the scaling rate and the amounts of deposit. This suggests that the number of $\mathrm{CaCO}_{3}$ nuclei strongly affects the scaling rates (Chao et al., 2014a). Moreover, SQCM could detect $\mathrm{CaCO}_{3}$ nuclei, even at very low supersaturation coefficient $(\delta=4)$. Recently, Chao et al. showed, by using Small Angle X-rays Scattering (SAXS) spectroscopy, that $\mathrm{CaCO}_{3}$ nuclei were present in synthetic water before the homogeneous precipitation (Chao et al., 2014b). These $\mathrm{CaCO}_{3}$ nuclei can be detected also in the early stage of the experiments with this measurement (Demichelis et al., 2011). 
1 It should be noticed that the scaling rate $\mathrm{V}_{\mathrm{s}}$, on a pre-calcified surface, was constant over time

2 for given experimental conditions. For each $\delta$ value, the scaling rate $\mathrm{V}_{\mathrm{s}}$ can be calculated from

3 the slope of the linear regression related to the mass change vs time curve (Fig. 3). $\mathrm{V}_{\mathrm{s}}$

4 characterizes the scaling propensity of water (Chao et al., 2014a). A plot of the logarithm of

5 scaling rate as a function of the logarithm of the supersaturation coefficient could be linearly

6 fitted using equation 9, as detailed in the Materials and Methods part (Figure 5).

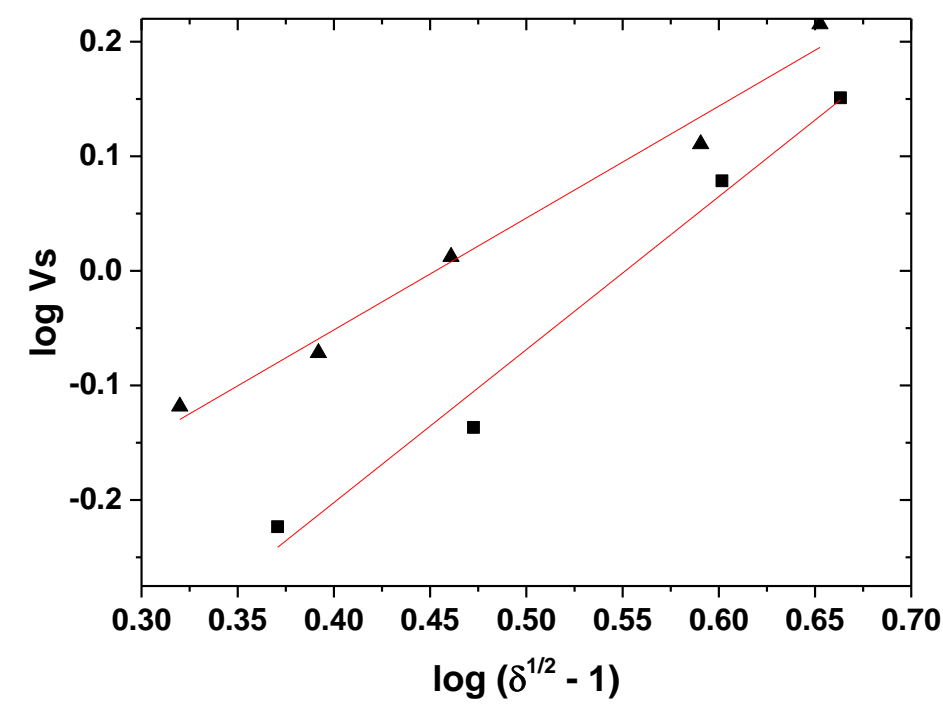

$9 \quad$ Figure 5: Logarithm of the scaling rate $V_{S}$ as a function of the logarithm of $\delta$ at $(\boldsymbol{\square}) 30^{\circ} \mathrm{C}$ and ( $\Delta$ ) $40^{\circ} \mathrm{C}$ (flow rate $=2 \mathrm{~mL} \cdot \mathrm{min}^{-1}$, pre-calcified surface of the sensor made of pure calcite).

The data related to the linear fit are summarized in Table 2.

Table 2: Summary of data obtained from fitted curves (see text for signification of the parameters).

\begin{tabular}{cccc}
\hline $\mathrm{T}\left({ }^{\circ} \mathrm{C}\right)$ & $\mathrm{k} / \mathrm{SI}$ & $\mathrm{n}$ & $\mathrm{R}^{2^{*}}$ \\
\hline 30 & 0.19 & 1.3 & 0.95 \\
\hline 40 & 0.36 & 1 & 0.98
\end{tabular}

* Goodness-of-fit measure for the linear regression model. 
As shown in Figure 4, the scaling rates of calcium carbonate were found to depend strongly on the value of the supersaturation level of the studied solution, for a given water (Zhang et al., 2001; Chen et al., 2005; Parlaktuna and Okandan, 1989; Abdel-Aal et al., 2002; Ben Amor et al., 2004). The scaling rate increased with $\delta$, in agreement with the results from literature. For example, Al Nasser et al. (Al Nasser et al., 2013) showed that the deposit rate on steel plates immerged in a scale forming solution increased when $\delta$ increased. Koutsoukos and Kontoyannis (Koutsoukos and Kontoyannis, 1984) measured the scaling rate of calcium carbonate precipitation from aqueous solution by following the disappearance of calcium ion over time. They showed that the scaling rate increased with the supersaturation coefficient. It must be noted that the orders of reaction $n$ shown in Table 2 are of the same order of magnitude as those reported in literature. Indeed, an apparent order of $1.3\left(\mathrm{~T}=22^{\circ} \mathrm{C}\right)$ was reported for the $\mathrm{CaCO}_{3}$ growth on nuclei (Packter, 1968). Moreover, Kitano and Hood (Kitano and Hood, 1965) found a reaction order of $c a 1$ for the growth of $\mathrm{CaCO}_{3}$. Parsiegla and Katz (Parsiegla and Katz, 1999) have reported an apparent order of 1 for calcite growth at low $\mathrm{pH}$ and low carbonate concentration. However, in their experiment they have investigated the kinetics of calcite growth. In this work, the $\mathrm{CaCO}_{3}$ layer was immobilized on a gold surface, and the scaling rate is related to the adsorption of nuclei formed in solution, likely as in a real scaling phenomena. In "natural conditions", scaling phenomena occur on a surface for moderate supersaturation levels.

\subsection{Influence of the temperature on scaling rate in synthetic water}

SQCM was performed at higher temperature. The choice of the higher but moderate temperature $\left(40^{\circ} \mathrm{C}\right)$ prevent the risk of precipitation of water at the beginning of the experiment. Figure 4 shows that the scaling rates established at $40^{\circ} \mathrm{C}$ were higher than those obtained at $30^{\circ} \mathrm{C}$. This result is in agreement with previous studies (Al Nasser and Al Salhi, 
1 2013; Ben Amor et al., 2004). Indeed, the solubility of $\mathrm{CaCO}_{3}$ decreases when the

2 temperature increases (Plummer and Busenberg, 1982) and the temperature dependence on

3 the scaling rate may affect the growing process on the pre-calcified surface (Hillig, 1966).

4 According to the Arrhenius law, the calculated activation energy (from temperatures $\mathrm{T}=30^{\circ} \mathrm{C}$

5 and $40^{\circ} \mathrm{C}$ ) in the experimental conditions of this work was found to be $22 \mathrm{~kJ} \cdot \mathrm{mol}^{-1}$.

In literature, values of activation energies have been reported for surface controlled processes involving $\mathrm{CaCO}_{3}$ precipitation on crystal seeds. For example, Koutsoukos and Kontoyannis (Koutsoukos and Kontoyannis, 1984) found an apparent activation energy of $155 \mathrm{~kJ} \cdot \mathrm{mol}^{-1}$ for a growth process on $\mathrm{CaCO}_{3}$ seeds, suggesting that the calcium carbonate precipitation was surface-controlled in aqueous solution. An activation energy of $46 \mathrm{~kJ}^{\mathrm{mol}}{ }^{-1}$ was also reported for crystal growth on seed crystals of calcite (Nancollas and Reddy, 1971; Cassford and al., 1983; Xyla et al., 1991). In the present work, it must be noticed that the activation energy $\left(22 \mathrm{~kJ} \cdot \mathrm{mol}^{-1}\right)$ is related to a scaling process on an immobilized $\mathrm{CaCO}_{3}$ layer. see if the activation energy determined in this study is related to diffusion (Fig. S2 in Supplementary Information). It was shown, by using the SQCM set-up with synthetic water $\left(\mathrm{T}=30^{\circ} \mathrm{C}, \delta=20\right.$, pre-calcified surface of the sensor made of pure calcite) that the kinetics of scale deposition increased with the flow rate. This suggests that the kinetics of scale deposition may be controlled by the diffusion of ions and/or $\mathrm{CaCO}_{3}$ nuclei in solution. In a previous work, the activation energy related to the dissolution process of vaterite was found to be $24 \mathrm{~kJ} \cdot \mathrm{mol}^{-1}$ and was typical of the ion diffusion in aqueous solution (Brecevic and Kralj, 2007). 
2 comparable amount of bicarbonate and calcium, and a very low content in other ions, especially $\mathrm{Mg}^{2+}$ and $\mathrm{Cl}^{-}$ions. The FT-IR spectrum of the precipitate obtained from the Salvetat water is very similar to that of the pure calcium carbonate used for synthetic water (Fig. S1 in Supplementary Information). In addition, there are no silicates or phosphates species detectable in Salvetat water precipitate. As the Salvetat water is naturally aggressive, the presence of $\mathrm{CaCO}_{3}$ germs at the beginning of the SQCM experiment is avoided. Thus, the Salvetat water can be used to show the influence on scaling rate of elements that are not well characterized but potentially present in water, i.e. natural organic substances and/or suspended

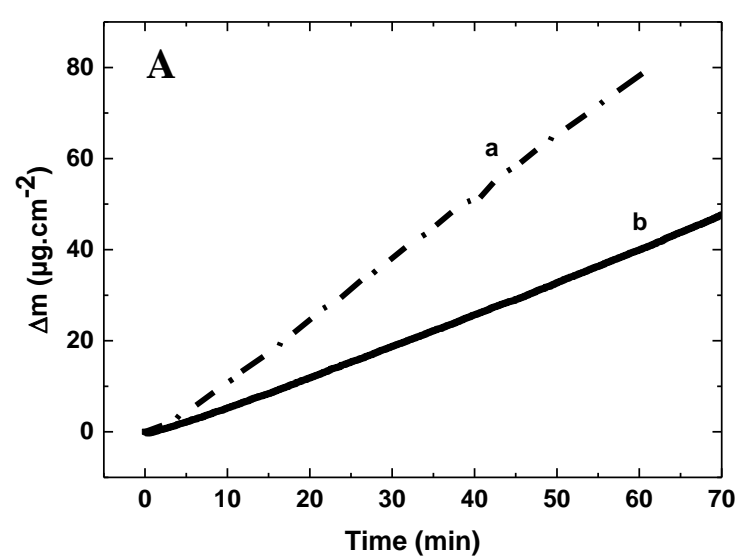
matter.

The mass change of the scale quantity deposited on the pre-calcified surface from a synthetic water $\left(\left[\mathrm{Ca}^{2+}\right]=200 \mathrm{mg} \cdot \mathrm{L}^{-1}\right)$ and from a natural water (Salvetat, $\left.\left[\mathrm{Ca}^{2+}\right]=180 \mathrm{mg} \cdot \mathrm{L}^{-1}\right)$ were investigated by using the SQCM set-up (Figure 6):

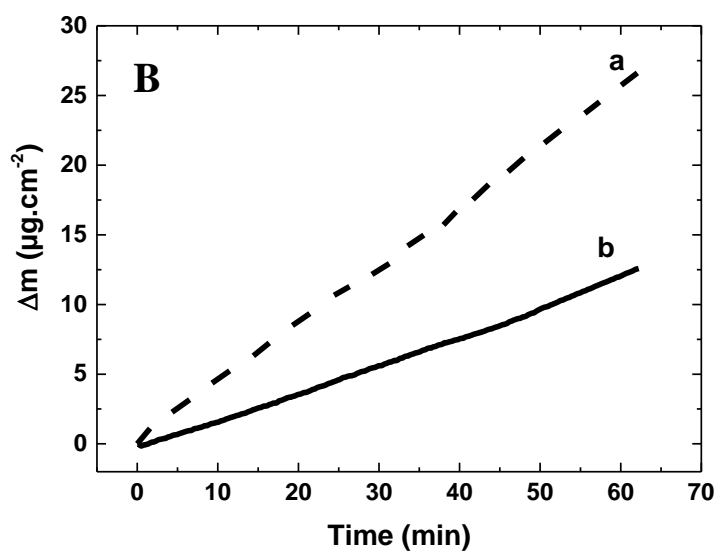

Figure 6: (A) Mass change of scale deposited from (a) synthetic water ([Ca $\left.{ }^{2+}\right]=200 \mathrm{mg} \cdot \mathrm{L}^{-1}$, $\delta=20)$, (b) Salvetat water $(\delta=21)$. (B) Mass change of scale deposited from (a) Salvetat water $(\delta=8.45)$ and (b) Salvetat water diluted at $50 \%(\delta=9.60)$. Flow rate $=2 \mathrm{~mL} \cdot \mathrm{min}^{-1}, 30^{\circ} \mathrm{C}$, precalcified surface of the sensor made of pure calcite. 
Figure 6A shows that the SQCM is sensitive enough to determine the mass change in

2 natural water. The results showed that the scaling rate is lower for the natural water (curve b) than for the synthetic water (curve a). A previous study using electrochemical QCM (EQCM) has shown that organic molecules with carboxylic groups were very efficient to inhibit towards calcium carbonate scaling (Peronno et al., 2015). The effect of humic substances (Chao et al., 2014a) and kaolinite (Chao, 2016) were investigated by using SQCM. It was shown that the average scaling rate decreased when the humic substance concentration increased. SQCM also showed that kaolinite had little influence on the scaling propensity of water. A slowdown of nucleation kinetics was also observed in the presence of clay suspensions (Hui et al., 2004).

As previously discussed the Salvetat water is, very close to synthetic water but also contains some elements that are not well characterized as organic substances (TOC of 0.4 $\mathrm{mg} / \mathrm{L}$ ) or inorganic substances. The data shown in Figure 6 shows that those additional elements which decrease the scaling rate. These elements could corresponds to organic molecules, humic substances or suspended matter (clay...), in line with the results of the literature (Ladel and Leroy, 1997). They may poison the active sites of the $\mathrm{CaCO}_{3}$ crystals and thus strongly influence the deposition process. The surface charges of these elements could play a role in those mechanisms. For example, Hui et al. showed that the antiscaling effect of clays is maximum if the clay displays the maximum quantity of suspended materials as well as a highly negative zeta $(\zeta)$ potential (Hui et al., 2004).

Figure $6 \mathrm{~B}$ shows a comparison of the mass change of scale deposition for Salvetat water (curve a) and Salvetat water diluted at $50 \%$ (curve b). The supersaturation coefficient is slightly higher for Salvetat water diluted at 50\% than for Salvetat water (9.60 and 8.45 respectively). It must be noticed that the scaling rate is higher for Salvetat water than for Salvetat water diluted at $50 \%$. Indeed, the $\mathrm{Ca}^{2+}$ concentration is lower, and the scaling rate 
decreased when the concentration of calcium decreased, i.e. the number of $\mathrm{CaCO}_{3}$ nuclei decreased. The supersaturation coefficient is therefore not the only one parameter which influences the scaling rate.

\section{Conclusion}

In this work, a scaling quartz crystal microbalance (SQCM) with a pre-calcified surface constituted of pure calcite was used to assess the scaling propensity of synthetic or natural water.

The scaling rate on the pre-calcified surface was markedly dependent on solution supersaturation coefficient and temperature; it increased with the increase of these two parameters. For the first time, the activation energy related to a scaling process on an immobilized $\mathrm{CaCO}_{3}$ layer $\left(22 \mathrm{~kJ} . \mathrm{mol}^{-1}\right)$ was evaluated by using SQCM. The kinetics of scale deposition increased with the flow rate. This phenomenon may be therefore controlled by the diffusion of ions and/or $\mathrm{CaCO}_{3}$ nuclei in solution.

Finally, the SQCM set-up is sensitive enough to show that scaling rate is lower in natural water, compared to synthetic water in similar conditions. This may be due to the presence of the organic compounds or particle suspensions in natural water which could have some significant inhibition effects.

This work confirms that SQCM is a convenient and sensitive tool to measure in situ $\mathrm{CaCO}_{3}$ nuclei deposit both in synthetic and natural water. Even at the beginning of the experiment with small $\mathrm{CaCO}_{3}$ particles at low concentration, it could be used as an in situ sensor to assess the scaling propensity for a given water, immerged in a main circuit or in a bypass. This could be interesting for some industrial applications (i.e. cooling system or circuit). It could also be used profitably to assess efficiency of an antiscalant treatment by considering the scaling propensity of water. 


\section{Acknowledgement}

3 Cyrille Bazin (LISE) is gratefully thanked for technical assistance on X-Ray diffraction

4 experiment. Axel Desnoyers de Marbaix (LISE) is thanked for the manufacturing of the QCM 5 cell.

6

7 


\section{$1 \quad$ Figure captions}

2 Figure 1: Scheme of a SQCM set up.

3 Figure 2: XRD spectrum of the $\mathrm{CaCO}_{3}$ layer formed during the pre-calcifying process. $\mathrm{C}$ :

4 calcite.

5 Figure 3: Curves of mass change as a function of time for synthetic water with (a) a pre6 calcified surface (pure calcite) (scaling time $V s=1.2 \mu \mathrm{g} \cdot \mathrm{cm}^{-2} \cdot \mathrm{min}^{-1}$ ) and (b) a bare gold 7 surface (initial $\left[\mathrm{Ca}^{2+}\right]=200 \mathrm{mg} / \mathrm{L}, \mathrm{T}=30^{\circ} \mathrm{C}$, flow rate $=2 \mathrm{~mL} \cdot \mathrm{min}^{-1}, \delta=40$ ).

8 Figure 4: Mass change as a function of time: influence of the supersaturation coefficient

$9\left(\mathrm{~T}=30^{\circ} \mathrm{C}\right.$, flow rate $=2 \mathrm{~mL} \cdot \mathrm{min}^{-1}$, pre-calcified surface of the sensor made of pure calcite $)$.

Figure 5: Logarithm of the scaling rate $V_{S}$ as a function of the logarithm of $\delta$ at $(\mathbf{m}) 30^{\circ} \mathrm{C}$ and

( $\Delta$ ) $40^{\circ} \mathrm{C}$ (flow rate $=2 \mathrm{~mL} \cdot \mathrm{min}^{-1}$, pre-calcified surface of the sensor made of pure calcite).

Figure 6: (A) Mass change of scale deposited from (a) synthetic water ([Ca $\left.{ }^{2+}\right]=200 \mathrm{mg} . \mathrm{L}^{-1}$, $\delta=20)$, (b) Salvetat water $(\delta=21)$. (B) Mass change of scale deposited from (a) Salvetat water $(\delta=8.45)$ and (b) Salvetat water diluted at $50 \%(\delta=9.60)$. Flow rate $=2 \mathrm{~mL} \cdot \mathrm{min}^{-1}, 30^{\circ} \mathrm{C}$, precalcified surface of the sensor made of pure calcite.

\section{Table captions}

Table 1: Concentration of ions in Salvetat ${ }^{\circledR}$ water.

Table 2: Summary of data obtained from fitted curves (see text for signification of the parameters). 


\section{References}

Abd-El-Khaled, D. E., Abd-El-Nabey, B. A., 2013. Evaluation of sodium hexametaphosphate as scale and corrosion inhibitor in cooling water using electrochemical techniques.

\section{Desalination 311, 227-233.}

Abdel-Aal, N., Satoh, K., Sawada, K., 2002. Study of the adhesion mechanism of $\mathrm{CaCO}_{3}$ using a combined bulk chemistry/QCM technique. Journal of Crystal Growth 245, 87-100.

Al Nasser, W. N., Al Salhi, F. H., 2013. Scaling and aggregation kinetics determination of calcium carbonate using inline technique. Chemical Engineering Science 86, 70-77.

Ben Amor, M., Zgolli, D., Tlili, M. M., Manzola, A. S., 2004. Influence of water hardness, substrate nature and temperature on heterogeneous calcium carbonate nucleation. Desalination 166, 79-84.

Bizet, K., Gabrielli, C., Perrot, H., 2000. Immunodetection by quartz crystal microbalance A new approach for direct detection of rabbit $\operatorname{IgG}$ and peroxidase. Applied Biochemistry and Biotechnology 89, 139-150.

Blum, A. E., Yund, R.A., Lasaga, A. C., 1990. The effect of dislocation density on the dissolution rate of quartz. Geochim. Cosmochim. Acta 54, 283-297.

Brecevic, L., Kralj, D., 2007. On calcium carbonates: from fundamental research to application. Croat. Chem. Acta 80, 467-484.

Cassford, G. E., House, W. A., Pethybridge, A. D., 1983. Crystallisation kinetics of calcite from calcium bicarbonate solutions between 278.15 and 303.15 K. J. Chem. Soc. Faraday Trans 79, 1617-1632.

Chao, Y., O. Horner, F. Hui, J. Lédion, H. Perrot, 2014a. Direct detection of calcium carbonate scaling via a pre-calcified sensitive area of a quartz crystal microbalance, Desalination 352, 103-108. 
1 Chao, Y., Horner, O., Vallée, P., Meneau, F., Alos-Ramos, O., Hui, F., Turmine, M., Perrot,

2 H., Lédion, J., 2014b. In situ probing calcium carbonate formation by combining fast

3 controlled precipitation method and small-angle X-ray scattering. Langmuir 30, 3303-3309.

4 Chao, Y., 2016. Scaling Potential determination of water circuit by the use of an ultrasensitive

5 crystal quartz microbalance. 2013, PhD Thesis, Université Pierre et Marie Curie (France).

6 Chen, T., Neville, A., Yuan, M., 2005. Calcium carbonate scale formation - assessing the 7 initial stages of precipitation and deposition. J. Petrol. Sci. Eng. 46, 185-194.

8 Demichelis, R., Raiteri, P., Gale, J. D., Quigley, D., Gebauer, D., 2011. Nature

9 Communications 2, 1-8.Donnet, M., Aimable, A., Lemaître, J., Bowen, P., 2010. Contribution of aggregation to the growth mechanism of seeded calcium carbonate precipitation in the presence of polyacrylic acid. J. Phys. Chem B 114, 12058-12067.

Gabrielli, C., Keddam, M., Maurin, G., Perrot, H., Rosset, R., Zidoune, M., 1996. Estimation of the deposition rate of thermal calcareous scaling by the electrochemical impedance technique. Journal of Electrochemical Chemistry 412, 189-193.

Gabrielli, C., Keddam, M., Khalil, A., Maurin, G., Perrot, H., Rosset, R., Zidoune, M., 1998. Quartz crystal microbalance investigation of electrochemical calcium carbonate scaling. J. Electrochem. Soc. 145, 2386-2396.

Gabrielli, C., Maurin, G., Poindessous, G., Rosset, R., 1999. Nucleation and growth of calcium carbonate by an electrochemical scaling process. Journal of Crystal Growth 200, $236-250$.

Gauthier, G., Chao, Y., Horner, O., Alos-Ramos, O., Hui, F., Lédion, J., Perrot, H., 2012. Application of the Fast Controlled Precipitation method to assess the scale-forming ability of raw river waters. Desalination 299, 89-95.

Hasson, D., Bramson, D., Limoni-Relis, B., Semiat, R., 1996. Influence of the flow system on the inhibitory action of $\mathrm{aCO}_{3}$ scale prevention additives. Desalination 108, 67-79. 
1 Hillig, W. B., 1966. A derivation of classical two-dimensional nucleation kinetics and the

2 associated crystal growth laws. Acta Metallurgica 14, $1868-1869$.

3 Hui, H., Lédion, J., 2002. Evaluation methods for the scaling power of water. Eur. J. Water

$4 \quad$ Qual., 33, $41-52$.

5 Hui, F., Yang, Y., Lédion, J., 2003. Evaluation gravimétrique des vitesses d'entartrage sur 6 tubes témoins. Journal Européen d'Hydrologie 34, 221 - 234.

7 Hui, F., Palmier, C., Jan, Y., Orain, Y., Baron, J., Lédion, J., 2004. Influence of clay suspensions on scaling. European Journal of Water Quality 35, $11-28$.

Keysar, S., 1994. Effect of surface roughness on the morphology of calcite crystallizing on mild steel. Journal of Colloid and Interface Science 162, 311 - 319.

Kitano, Y., Hood, D. W., 1965. The influence of organic material on the polymorphic crystallization of calcium carbonate. Geochimica et Cosmochimica Acta 29, 29 - 41.

Koutsoukos, P. G., Kontoyannis, C. G., 1984. Precipitation of calcium carbonate in aqueous solutions. J. Chem. Soc. Faraday trans. 1, 80, $1181-1192$.

Ladel, J., Leroy, P., 1997. Mise en évidence de l'effet inhibiteur de métabolites d'algues planctoniques sur la précipitation du carbonate de calcium dans les eaux naturelles d'origine superficielle. Journal Européen d'Hydrologie 28, 69 - 86.

Lédion, J., Leroy, P., Labbé, J. P., 1985. Détermination du caractère incrustant d'une eau par un essai d'entartrage accéléré. T.S.M. L'eau, $80^{\text {ème }}$ année, 323 - 328.

Legrand, L., Poirier, G., Leroy, P., 1981. Les équilibres carboniques et l'équilibre calcocarbonique dans les eaux naturelles. Eyrolles, Paris.

Leroy, P., Lin, W., Ledion, J., Khalil, A., 1993. Caractérisation du pouvoir entartrant des eaux à l'aide d'essai d'électrodéposition - étude comparative de plusieurs méthodes. J. Water SRTAqua 42, 23 - 29. 
1 Morse, J. W., Arvidson, R. S., Lüttge, A., 2007. A calcium carbonate formation and

2 dissolution. Chem. Rev. 107, $342-381$.

3 Nancollas, G. H., Reddy, M. M., 1971. The crystallization of calcium carbonate, II. Calcite

4 growth mechanism. Journal of Colloid an Interface Science 37, $824-830$.

5 Packter, A., 1968. The precipitation of sparingly soluble alkaline-earth metal and lead salts:

6 nucleation and growth orders during the induction time. J. Chem. Soc. (A), 859-862.

7 Parlaktuna, M., Okandan, E., 1989. The use of chemical inhibitors for prevention of calcium 8 carbonate scaling. Geothermics 18, $241-248$.

9 Parsiegla, K. I., Katz, J. L., 1999. Calcite growth inhibition by copper(II). I. Effect of supersaturation. Journal of Crystal Growth 200, 213 - 226.

Peronno, D., Cheap-Charpentier, H., Horner, O., Perrot, H., 2015. Study of the inhibition effect of two polymers on calcium carbonate formation by fast controlled precipitation method and quartz crystal microbalance. Journal of Water Process Engineering 7, 11-20.

Plummer, N. L., Busenberg, E., 1982. The solubilities of calcite, aragonite and vaterite in $\mathrm{CO}_{2}-\mathrm{H}_{2} \mathrm{O}$ solutions between 0 and $90^{\circ} \mathrm{C}$, and an evaluation of the aqueous model for the system $\mathrm{CaCO}_{3}-\mathrm{CO}_{2}-\mathrm{H}_{2} \mathrm{O}$. Geochimica et Cosmochimica Acta 46, $1011-1040$.

Sauerbrey, G., 1959. Verwendung von Schwingquarzen zur Wägung dünner Schichten und zur Mikrowägung. Zeitschrift für Physik 155, 206 - 222.

Tlili, M. M., Benamor, M., Gabrielli, C., Perrot, H., Tribollet, B., 2003. Influence of the interfacial $\mathrm{pH}$ on electrochemical $\mathrm{CaCO}_{3}$ precipitation. Journal of the Electrochemical Society 150, C765-C771.

Xyla, A. G., Giannimaras, E. K., Koutsoukos, P. G., 1991. The precipitation of calcium carbonate in aqueous solutions. Colloids and Surfaces 53, $241-255$.

Yang, Q., 2002. Investigation of induction period and morphology of $\mathrm{CaCO}_{3}$ fouling on heated surface. Chemical Engineering Science 57, 921 - 931. 
1 Zhang, Y., Shaw, H., Farquhar, R., Dawe, R., 2001. The kinetics of carbonate scaling -

2 application for the prediction of downhole carbonate scaling. J. Petrol. Sci. Eng. 29, 85 - 95. 